\title{
A Flood Model for the Chalakudy River Area
}

\author{
Georg Gutjahr, Sachin Das
}

\begin{abstract}
The Kerala flood in the August of 2018 was the most severe flood in South India in almost a century. Kerala was under high alert.14 districts were given red alert. Over 5 million people lost their homes and many of them were affected with fever and cold and several other diseases. After the flood, over 1 million people had to stay in relief camps for several months. Around 3200 relief camps were opened to help the people. This works presents a model of the flood for Chalakudy river area. The area was one of the most severely affected areas during the flood. The model is a adaptation of a model that was introduced by Kourgialas and Karatzas for river basins in Greece. The model has various applications, for example, in finding proper flood management strategies in coastal cities and villages and in organizing the relief work after a flood.
\end{abstract}

Index Terms-geographic information system, coastal regions, relief distribution, flood modelling.

\section{INTRODUCTION}

Kerala with a total area of 38.8 square $\mathrm{km}$ is a state in south India. Southwest and Northeast monsoons control the rainfall in Kerala. Kerala experiences $90 \%$ of rainfall and storm during monsoon season. It also results in overflow of water in all the rivers. The consistent and overwhelming rainfall during the monsoon seasons in the summer of 2018 resulted in a severe flood disaster [1].

During the beginning of the monsoon season, Kerala experienced $42 \%$ above normal rainfall. The first flood event happened at the end of July 2018 due to the result of heavy rainfall which was started during the month of June and July. The state experienced high torrent again during the beginning days of august 2018 at several places in Kerala. A maximum of about $1398 \mathrm{~mm}$ of rainfall is experienced at the various districts of Kerala. As a result of this heavy rain, the level of water in different reservoirs and dams (35 out of 45) reached more than $90 \%$ of their full capacity and the water from these were released. Another heavy rainstorm cause to happen from the end of second week of august and continued till third week which resulted in a big disaster of inundation in several Kerala districts. As per the India Meteorological Department's rainfall records, this calamity occurred due to the heavy rainfall is similar to the cyclone experienced in the year 1924. Kerala had never witnessed such a terrific disaster

Revised Manuscript Received on July 10, 2019.

Georg Gutjahr, Center for Research in Analytics \& Technologies for Education, Amrita Vishwa Vidyapeetham, Kollam, Kerala, India.

Sachin Das, Department of Mathematics, Amrita Vishwa

Vidyapeetham, Kollam, Kerala, India. that resulted in the death of about 400 or more persons during the past 90 years [2].

In this paper we consider the Chalakudy river area in detail. The Chalakudy River is the fifth largest river in Kerala.The main part of the river flows through two districts: Ernakulam in the south and Thrissur in the north. The Chalakudy river area was one of the most severely affected areas during the flood. Uncommon precipitation events and flooding caused a great human loss and also resulted in damage of ground-works. Hundreds of people from the area had to be evacuated and stayed in relief camps for multiple months. Many people volunteered to help with the relief distribution for commodities such as food water medicines and clothes. The commodities from people as well as organizations were collected at government depots. During the first few days after the flood, considerable uncertainty existed how commodities should be transported to the camps since it was unknown which areas are traversable.

This paper discusses a flood model for the Chalakudy river area. It can be applied to choose safe routes during an initial period of uncertainty during a flood. The model is a adaptation of a model by Kourgialas and Karatzas [3] for the prediction of river basins in Greece. The model divides the study area into five categories of flood risk, from low to high. These categories of flood risk are predicted based on six factors: elevation, slope, rainfall intensity, geology, land use, and flow accumulation. We used GIS data as input for the flood modelling and to find the high-risk flood regions. Using QGIS and ArcGIS tools the maps of different factors are modelled. All these six maps show the thematic effect of flood in high risk and low risk areas. Finally all the six modeled maps were combined to obtain the final flood hazard area of Chalakudy river basin.

\section{LITERATURE REVIEW}

Flood modelling is an important step for the better understanding and management of flood [4]-[5]. Models of different complexity have been proposed in the literature. We will briefly review some of these models. First one is the multivariate modelling of flood flows in which data of different floods occurred in the past were used as the input and flood leak, flood volume and flood duration are calculated by using shot noise method mainly for the flow of Narmada river [6]. Second one is the 2D hydraulic modelling for microscale flood risk analysis where the different land maps and geographical data are used as input for modelling. The model discussed here depends on the depth-averaged equations of mass and momentum [7]. 
For the determination of rainfall overflow response using different inputs such as local slope, hydraulic radius, coefficient of roughness, a different GIS based flood modelling approach called diffusive transport approach is used. Method used here is Diffusive Wave equation [8]. A fourth model for a flood vulnerability and risk mapping aims at finding the chance and risk of flooding in urban areas by considering the factors drainage, soil pattern, land-use and elevation. This is modeled by hierarchy processes using a GIS [9]. Another mathematical model is the stochastic and deterministic model which is used for providing the best means on accessing and subsequently lessening the susceptibility especially for the flood prone rural, urban areas with the topographic, longitudinal and cross-section of the river [10]. The short term rainfall can be predicted using different models such as ARIMA processes, neural networks or nearest neighbor models [11]. To access the flood hazard areas and for the proper flood management using historic rainfall data GIS modelling techniques can be used [3]. Flash flood susceptibility or flood susceptibility analysis can be modelled or mapped using slope angle or degree, plane curvature, topographic wetness index, land use, soil pattern and distance from the river as input [12]. A rapid method for finding the effective method for flood susceptibility is the statistical analysis and spatial modelling [13].

\section{FLOOD MODEL FOR THE CHALAKUDY RIVER AREA}

\section{Study Area}

The current study is to find Flood hazard risk zone maps of Chalakudy River basin using remote sensing and GIS tools. An image from the Landsat satellite is shown in Figure 1, were the red borders are used to indicate the study area. The study includes analysis of different factors for finding high risk zones such as Elevation, Land use, Slope, Geology, Rainfall intensity and Flow accumulation. To prepare the risk zone map, weighted method is adopted. The map thus modelled shows the details of the areas that are classified according to different intensity of hazard levels. With the help of these modelled maps, we can find different measures to reduce the risk and intensity of flood in the Chalakudy river basin.

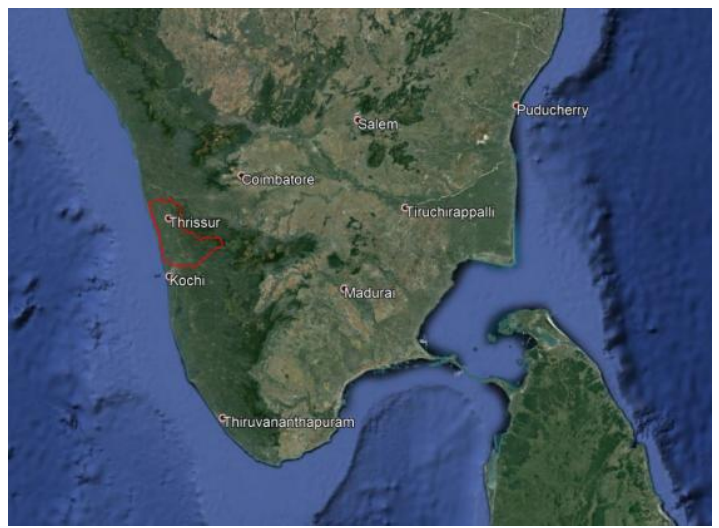

Fig. 1. Satellite image of South India and Sri Lanka. The study area is shown with red borders.

\section{Model}

The model of the flood hazard in the Chalakudy River basin is based on six factors that are stored in a Geographic Information System (GIS). QGIS is an open source geographic information system that helps in viewing, editing and modelling of geospatial data. Plugins are the most important tools that help accomplishing tasks in QGIS. All of these six factors were geo-referenced to the Coordinate System "World Geodetic System 1984" in QGIS.

Once maps of these six factors are prepared in a GIS, the weighted map is created by assigning weights and ranks to the thematic maps. The specific way to combine the maps of the risk factors is based on the work by Nektarios $\mathrm{N}$. Kourgialas \& George P. Karatzas in a European river basin [3].

To model these six factors, two districts of Kerala had to be considered since the Chalakudy river flows through these districts. The study area is masked out from the georeferenced map and the outline of the area has been developed. Figure 1 represents the georeferenced map of both Thrissur and Ernakulam district and the outline of the study area. The plug-in "Georeferencer GDAL" was used to create the georeferenced map and the outline [15]. Once the georeferenced map was obtained, maps for different factors are added as layers. These factors will now be described in more detail.

\section{Elevation}

Elevation is the height of the land above the sea level. For the study of elevation, digital elevation models (DEMs) developed by U.S Geological survey (USGS) were used [16]. They give information about the land surface. These DEMS are quadrangle-based and have been used extensively by the geospatial community. Some amount of pre-processing is needed and often multiple DEMs have to be combined to get a suitable representation of one area. We use the raster tool in QGIS on multiple satellite images to obtain an elevation map in a geo-referenced coordinate system.

As can be seen in Figure 1, the study area is a coastal region. In terms of elevation, large parts of the study area are close to the sea level. Figure 2 gives the pictorial representation of Elevation map of the Chalakudy river basin, where elevation is measured in meters.

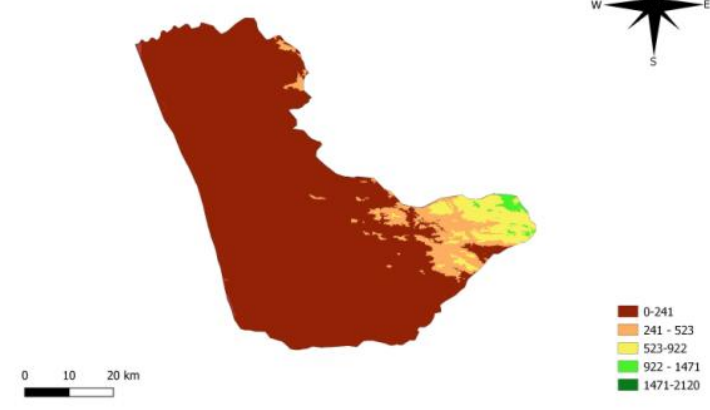

Fig. 2. Elevation map of the study area 


\section{Land use}

On the basis of the morphological features and physiochemical properties the soil, Kerala is classified into laterite, coastal alluvium, riverine alluvium, and kuttanad alluvium. The majority of the Thrissur district is covered by arable land which contains both irrigated and unirrigated land.

Paddy is cultivated in the valleys and low areas, while in the high ground areas, coconuts are cultivated. On the basis of land use, Ernakulam district is divided into arable, forest and waste lands [17]. The eastern part is mostly forest area, which also contains rubber and cashew plantations. Around $80 \%$ of the land can be used for cultivation and $10 \%$ is used for plantation as well as reserve forest.

Next to the arable land there is the forest land which is spread all over the middle part. Several plantations have replaced natural forests in Thrissur district. Rubber and cashew are the most common plantation crops in the area [14].

In the model, land use in the study area is classified into mixed forest land, agricultural lands, zones seaward area, cropland and pasture and shrub-brush-range land. Data of the land use in the study area is provided by the Indian Space Agency as part of the Bhuvan service. Figure 3 shows the land-use map. It can be seen that high risk flooded areas are near to the coast.

\section{E. Geology}

The geology of Kerala consists mainly of four rock patterns. The thickness of these rock formations can vary and the geological formations are not defined based on the thickness of the rock pattern. The four patterns that define the geology are [14]:

1) Charnockite belt

2) Gneissic belt

3) Granitic

4) Quaternaries of the coastal

Charnockite belt is the most common geological area in the Thrissur district. The other areas are widespread across the southern and western region. The geology of Ernakulam district mainly consists of charnockite belt. The eastern part consists of precambrian metamorphosed rocks and the western regions are covered by soft rock or unconsolidated coastal alluvium. Like the land use map, the Geological map is provided by the Bhuvan service.

The Figure 4 shows the geological model in Thrissur and Ernakulam district. For the flood risk, geology of the area is classified into moderate, low and high risk areas. This classification was developed by the Department of Mining and Geology of the Kerala Government [14],[17]. Figure 4 shows that in terms of geology, the high risk areas are again close to the coast.

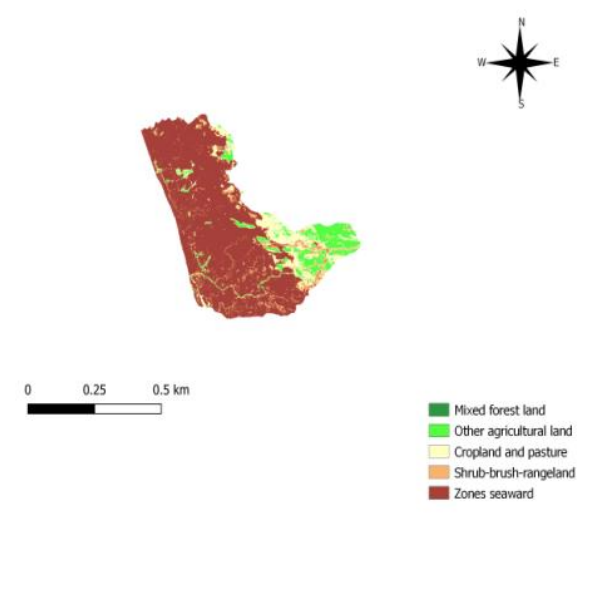

Fig. 3. Land use map
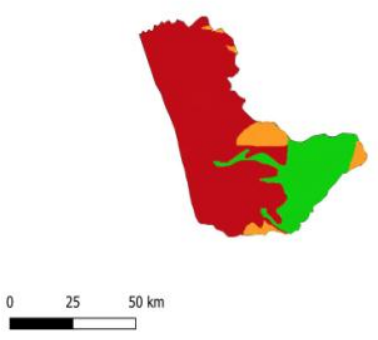

Fig. 4. Geology map 


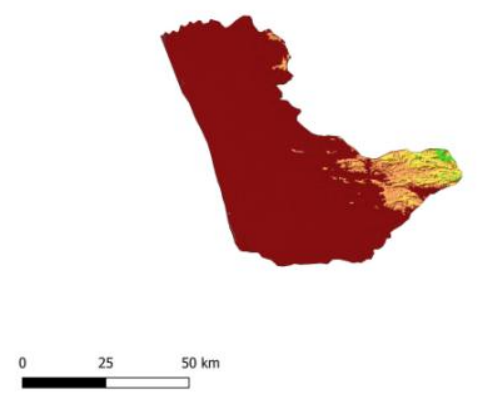

Fig. 5. Slope map

\section{Slope}

Slope is the angle or curve formed on an area. It has a major effect on flow accumulation and land use. As the water flows through several areas based on the type of soil the slope can be different in each region. The slope of an area has a great impact on soil erosion. The slope varies with increase in water level and increase in the water level also affects elevation of the land. In general, the large the slope, the lower the flood risk.

The slope in the study area is modelled in QGIS using the raster tool, which can also be used to find the hill shade and roughness. The slope data is obtained from the District Survey Report of Thrissur [14] and Ernakulam [17]. Figure 5 shows the flood risk based on the slope in the study area. The units in the maps are degrees of the slope. Once again, the high risk areas are found close to the coast.

\section{Rainfall intensity}

The intensity of rainfall (precipitation) are important factors in modelling flood-risk. In particular, flash flood events are usually preceded by intense rainfall. Also, rainfall intensity is important for land use as plants require a certain range of soil dampness.

The rainfall intensity is measured using the Modified Fourier Index [18] method,

$$
\sum_{K=1}^{12} n_{k}^{2} / R
$$

with $n_{k}$ the rainfall in the $\mathrm{k}$-th months in $\mathrm{mm}$ and $\mathrm{R}$ the annual rainfall in $\mathrm{mm}$. Monthly rainfall data is obtained from the Indian Meteorological Department Pune [19]. The modelling of rainfall intensity map is done by using previously recorded rainfall data. The meteorological data includes rainfall details of 17 stations located in the study area and surroundings. The map is modelled in ArcGIS using the inverse distance weighted method provided by the interpolation plug-in. The result is shown in Figure 6.

Fig. 6. Rainfall intensity map

\section{G. Flow accumulation}

Flow accumulation is a measurement for drainage in an area [20]. To calculate flow accumulation on a map, the Arc Hydro algorithm is used [20]. It builds a raster of agglomerated flow to each cell where a weighted component is exercised. Flow accumulation is then propagated throughout all cells of the raster. The result is the agglomerated flow of each cell, determined by combining the weight for all the cells that flow down into down-slope cell. Figure 7 displays the flow accumulation map.
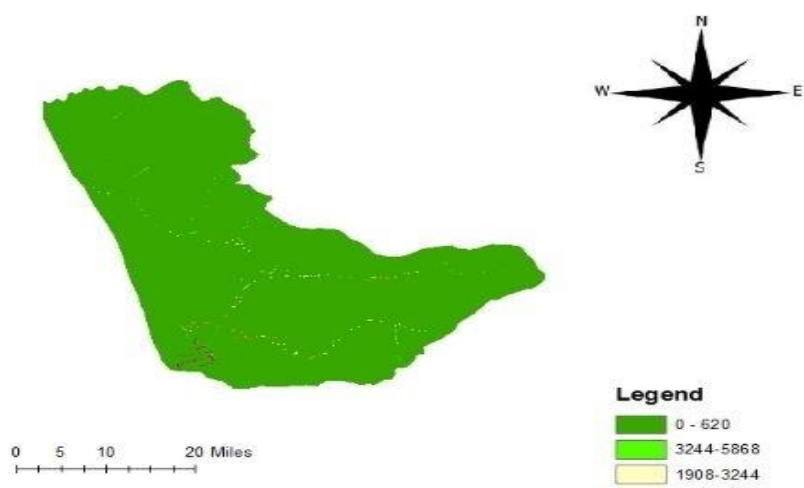

\section{H. Combined risk}

The six risk factors discussed above are combined into an overall flood hazard score by a method proposed by Kourgialas and Karatzas [3]. The method takes into account the interaction between the risk factors, for example that slope has a major effect on land use as well as on flow accumulation. Kourgialas and Karatzas used data from river basin in Greece to determine the parameters of the model.

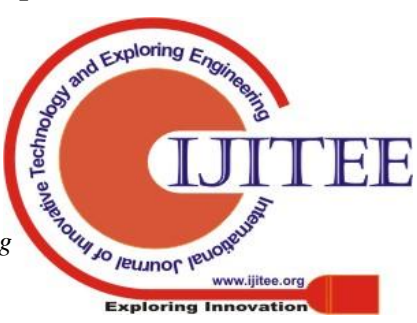


The GIS Model Builder was used to calculate the combined flood risk from the maps in Figures 2-7. The resulting combined flood risk map is shown in Figure 8.

The regions that are close to the coastal areas have a high flood risk. These areas are shown in red in the figure. The low risk areas are mainly mountains or high elevation areas so that water will not reach these areas easily. Rivers and canals have an important role in preventing the flood in high risk areas. Opening of dams and canals helps in the flow of water so that the water level in high risk areas can be decreased.

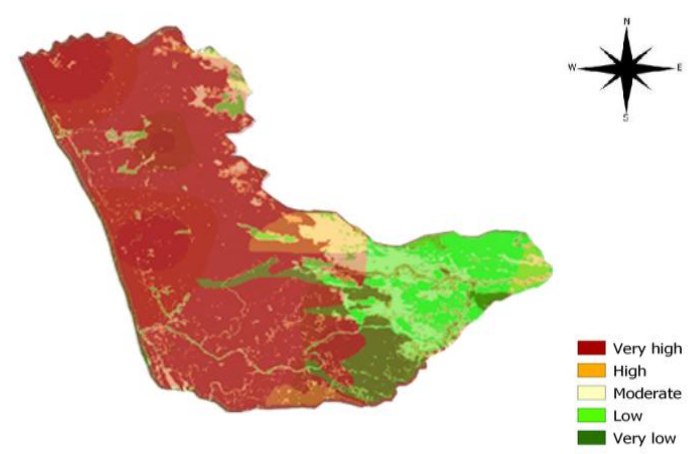

Fig. 8. Flood risk map of the study area

\section{Relief camps}

One application of the flood risk model, is to find safe routes after a flood. As an example, locations of the relief camps in the study area after the Kerala flood were kindly provided by the Kerala River Research Centre. For the distribution of relief commodities, teams of volunteers have to travel between these camps.

Figure 9 shows the georeferenced map with the relief camps and flooded area. Based combined map of the flood hazard, the safest routes between camps can be defined as the least-cost paths, with respect to the flood hazards; see next section.

Once the safe routes for the teams of volunteers are determined, the optimal distribution of relief commodities can be formulated as a team-orienteering problem; such team-orienteering problems have applications in many other areas where goods have to be distributed [21]-[22].

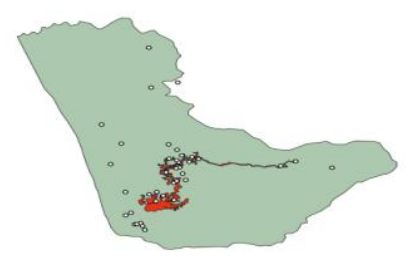

Fig. 9. Georeferenced map with the relief camps. The flooded area is shown in red.

\section{LEAST-COST PATH}

Least-cost analysis defines the cost of a path by integrating a cost function along the path. The path with the smallest cost between two points is called the least-cost path. In the present study, the cost is the flood risk, and the least-cost path can be thought of as the safest connection between two points.

In ArcGIS, the distance analysing tool helps in finding out the distance from a source to its destination. This tool can also incorporate costs. The user defines costs by a layer. It can also be a function of time or other criteria. In order to perform least-cost path analysis, three components are needed: source raster, cost raster, cost distance. Source raster defines the source to which the leas-cost path is calculated. Cost raster defines the cost to move through each raster cell.

While we use least-cost path to find the safest and best route to travel between a source and destination, least-cost path analysis has several other GIS applications. For example it is intensely used in the field of construction. It is also used by ecologist in monitoring wildlife movements [23].

Different algorithms can be used in order to obtain the least-cost path. On graphs, Dijkstra's algorithm is one such algorithm. On a raster, algorithms for finding the least-cost path create a so-called back-link raster [24].

\section{CONCLUSION}

This work presented a flood model for the Chalakudy river area. This area was heavily affected by the Kerala flood in the summer of 2018. The model is based on 6 factors: elevation, slope, land use, geology, flow accumulation, and rainfall intensity. These factors are combined to obtain the overall flood risk. Such model is very suitable for the implantation in a GIS. In this paper, we have used both QGIS and ArcGIS to implement the model. The flood model can be used to estimate safe routes between relief camps.

\section{REFERENCES}

1. V. Mishra, S. Aaadhar, H. Shah, R. Kumar, D. R. Pattanaik, and A. D. Tiwari, "The kerala flood of 2018: combined impact of extreme rainfall and reservoir storage," Hydrology and Earth System Sciences Discussions, 2018,pp.1-13

2. Central Water Commission, "Study report: Kerala floods of August 2018," tech. rep., Government of India, 2018.

3. N. N. Kourgialas and G. P. Karatzas, "Flood management and a gis modelling method to assess flood-hazard areas a case study," Hydrological Sciences Journal-Journal des Sciences Hydrologiques, vol. 56, no. 2, 2011,pp.212-225.

4. M. Geetha, M. Manoj, A. Sarika, M. Mohan, and S. N. Rao, "Detection and estimation of the extent of flood from crowd sourced images," in 2017 International Conference on Communication and Signal Processing (ICCSP),IEEE, 2017,pp. 0603-0608.

5. R. Guntha, S. Rao, M. Benndorf, and T. Haenselmann, "A comprehensive crowd-sourcing approach to urban flood management," in International Conference on Ubiquitous Communications and Network Computing, Springer, 2017, pp.13-24.

6. N.Goel, S. Seth, and S. Chandra, "Multivariate modelling of flood flows," Journal of Hydraulic Engineering, vol. 124, no. 2, 1998, pp.146-155.

7. J. Ernst, B. J. Dewals, S. Detrembleur, P. Archambeau, S. Erpicum, and M Pirotton, "Micro-scale flood risk analysis based on detailed $2 \mathrm{~d}$ hydraulic modelling and high resolution geographic data," Natural Hazards, vol. 55, no. 2, 2010, pp.181-209. 
8. Y. Liu, S. Gebremeskel, F. De Smedt, L. Hoffmann, and L. Pfister, "A diffusive transport approach for flow routing in gis-based flood modelling," Journal of Hydrology, vol. 283, no. 1-4, 2003,pp.91-106.

9. Y. Ouma and R. Tateishi, "Urban flood vulnerability and risk mapping using integrated multi-parametric AHP and GIS: Methodological overview and case study assessment," Water, vol. 6, no. 6, 2014, pp.1515-1545.

10. D. Dutta, S. Herath, and K. Musiake, "A mathematical model for flood loss estimation,” Journal of hydrology, vol. 277, no. 1-2, 2003, pp.24-49.

11. E. Toth, A. Brath, and A. Montanari, "Comparison of short-term rainfall prediction models for real-time flood forecasting," Journal of hydrology, vol. 239, no. 1-4, 2000, pp. 132-147.

12. K. Khosravi, H. R. Pourghasemi, K. Chapi, and M. Bahri, "Flash flood susceptibility analysis and its mapping using different bivariate models in Iran: a comparison between Shannons entropy, statistical index, and weighting factor models," Environmental monitoring and assessment, vol. 188 , no. 12 , p. $656,2016$.

13. M. Marconi, B. Gatto, M. Magni, and F. Marincioni, "A rapid method for flood susceptibility mapping in two districts of phatthalung province (Thailand): present and projected conditions for 2050," Natural Hazards, vol. 81, no. 1, 2016, pp. 329-346.

14. Department of Mining and Geology Kerala, "District survey report of minorminerals-thrissur."http://www.dmg.kerala.gov.in/docs/pdf/dsr/dsrthr .pdf. Accessed: 2019-04-15.

15. K. Menke, R. Smith, L. Pirelli, and J. Hoesen, Mastering QGIS. Packt Publishing Limited, 2nd ed., 2016.

16. “Earth explorer.” https://earthexplorer.usgs.gov. Accessed: 2019-04-15.

17. Department of Mining and Geology Kerala, "District survey report of minor minerals-Ernakulam." http://dmg.kerala.gov.in/docs/pdf/dsr/dsr ern.pdf. Accessed: 2019- 04-15.

18. R. P. C. Morgan, Soil erosion and conservation. John Wiley \& Sons, 2009.

19. "Indian meteorological department pune." http://www.imdpune.gov.in/ Accessed: 2019-04-15.

20. H. Schauble, O. Marinoni, and M. Hinderer "A GIS-based method to calculate flow accumulation by considering dams and their specific operation time," Computers \& Geosciences, vol. 34, no. 6, 2008, pp. 635646.

21. G. Gutjahr, L. C. Krishna, and P. Nedungadi, "Optimal tour planning for measles and rubella vaccination in Kochi, South India," in 2018 International Conference on Advances in Computing, Communications and Informatics (ICACCI), IEEE, 2018,pp. 1366-1370.

22. G. Gutjahr, K. A. Kamala, and P. Nedungadi, "Genetic algorithms for vaccination tour planning in tribal areas in Kerala," in 2018 International Conference on Advances in Computing, Communications and Informatics (ICACCI), IEEE, 2018,pp. 938-942.

23. M. J. De Smith, M. F. Goodchild, and P. Longley, Geospatial analysis: a comprehensive guide to principles, techniques and software tools. Troubador Publishing Ltd, 2007.

24. D. H. Douglas, "Least-cost path in GIS using an accumulated cost surface and slope lines,"Cartographica: the international journal for Geographic Information and Geovisualization, vol. 31,no. 3,1994, pp $37-51$.

\section{AUTHORS PROFILE}

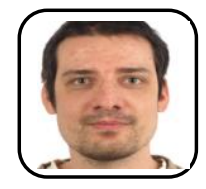

Dr. Georg Gutjahr received his $\mathrm{Ph}$. D. in Statistics from the University Of Vienna, Austria in 2010. He did a six year postdoc research at the University Of Bremen, Germany. He currently serves as an Assistant Professor in the Amrita Center for Research in Analytics and Technologies for Education, Amrita Vishwa Vidyapeetham. His research focuses mainly on data science, multiple testing theory and adaptive designs.

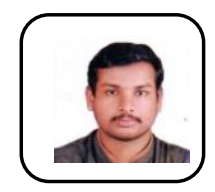

Sachin Das received his Graduation from Mahatma Gandhi University in the field of Mathematics in the year 2017. He is currently doing his final year Post Graduation in Mathematics in Amrita Vishwa Vidyapeetham, Amritapuri. He is currently working in Amrita CREATE as a project student. His work mainly focuses on modelling using ArcGIS and QGIS. 